\title{
Indoor Airborne Microflora in Various Section of a Tertiary Healthcare Centre in Rural Area of Ovia Northeast Edo State
}

\author{
Seto Saint T. ALADENIKA*, Mathew F. Olaniyan \\ Department of Medical Laboratory Science, Achievers University, Owo-Nigeria \\ *Corresponding author: aladeseto@gmail.com
}

Received July 02, 2014; Revised September 20, 2014; Accepted October 22, 2014

\begin{abstract}
This study was carried out to determined the variation in microbiota of five section of Igbinedion University Teaching Hospital Okada. Samples were collected using the settled plate techniques for the enumeration of bacterial and fungal isolates. The air specimens were collected three times; in the morning between the hours of 8 am and $10 \mathrm{am}$, in the afternoon between 12 noon and $2 \mathrm{pm}$ and in the evening between the hours of $4 \mathrm{pm}$ and $6 \mathrm{pm}$. The total heterotrophic microbial population of the five different units (wards) studied varied from wards to wards. The highest bacterial population was recorded in the afternoon between time $12 \mathrm{pm}$ and $2 \mathrm{pm}$ compared to the morning and evening, ranging from $5 \mathrm{cfu} / \mathrm{m} 3$ to $17 \mathrm{cfu} / \mathrm{m} 3$, with the accident and emergency ward recording the highest bacterial counts of $17 \mathrm{cfu} / \mathrm{m} 3$. The concentration of fungal population in air of the five different wards also followed the bacteria pattern in which highest fungi population were recorderd in afternoon $(16 \mathrm{cfu} / \mathrm{m} 3)$. At the three different times of study, the Accident and emergency ward, male ward, female ward as well as children wards show high yield fungal isolates. Five bacteria were isolated, namely; Pseudomonas aeruginosa, Staphylococcus aureus, Escherichia coli, Klebsiella aerogenes and Proteus mirabilis and identified accordingly. Aspergillus sp, Penicillum sp, and Mucor sp, were three fungi genera isolated. The degree of frequency of microbial distribution was high in the accident and emergency ward but lower in operating room (theatre). Accident and emergency ward my serve as source of infection in this hospital hence there should be an increase in level of hygiene in this unit also human movement should be limited scince they often serve as souces of pathogen.
\end{abstract}

Keywords: indoor airborne, microflora, tertiary healthcare, pathogen, rural area

Cite This Article: Seto Saint T. ALADENIKA, and Mathew F. Olaniyan, "Indoor Airborne Microflora in Various Section of a Tertiary Healthcare Centre in Rural Area of Ovia Northeast Edo State." American Journal of Infectious Diseases and Microbiology, vol. 2, no. 4 (2014): 86-90. doi: 10.12691/ajidm-2-4-3.

\section{Introduction}

When properly ventilated the Hospitals and other healthcare facilities complex serve as an environments which provides comfort for patients provided hazardous emissions are properly controlled [1,2]. However, patients may serve as source of microbial contaminant in hospital enviroment thereby distributing pathogens to the hospital staff and fellow patients as well as visitors [3]. The primary role of hospitalization and medical procedures are inted toward cure of diseases, but if not properly manage they can sometimes introduce pathogenic microorganisms into the body and enviroment hence initiate a nosocomial infection (NI) [4].

The most important source of airborne pathogens inside the hospital is the infected patient [5]. Airborne transmission occurs when pathogenic microorganisms are transferred from an infected to a susceptible individual via the air [4]. The predominant mechanism that makes the pathogens airborne is the production of aerosol droplets by sneezing or coughing, and their subsequent loss of water which allows them to float in the air over considerable distances and for a long time [6]. Biological aerosols contain bacteria, viruses, yeasts, molds and fungal spores $[7,8]$. Under special clinical circumstances, skin lesions may also be a source of airborne particles [5].

In spite of environmental conditions, e.g. dryness, temperatures and ultraviolet radiation, which may prevent microorganisms from growing in unfavourable environments, they still reach new hosts through the air. Some bacteria, particularly Gram-positive bacteria such as Streptococcus pneumoniae and Staphylococcus aureus, can survive for several months in dust particles. Also, fungal spores and viruses can survive for longer periods of time. The incidence of airborne infections has increased in recent years, because many new buildings are sealed and have self-contained circulating air systems for temperature control $[9,10]$.

Controlling airborne pathogens in healthcare facilities is not only important for the safety of the patient, but it is also important for hospital personnel. Various contamination control procedures can limit exposure and risk of infection [11]. Although it is not possible to eliminate all 
NI, their incidence can be significantly reduced by implementation of appropriate infection control policies [12]. There is a demand to reduce airborne microorganisms and their fall out (the bioburden of microorganisms causing infection in healthcare facilities). Furthermore, it is important to identify and accumulate bioburden data of these facilities where the maintenance of a clean environment and the accumulation of data on airborne microorganisms is required $[13,14]$. The counting and identification of microbes in air is not an easy task. Various methods are used and these can be divided into four groups: counts of colony forming units per cubic meter of air $\left(\mathrm{CFU} / \mathrm{m}^{3}\right)$; counts of CFU on settle plates; counts under a microscope; and measurement of a chemical component of the microbial cells per cubic meter of air [15]. There is no single method of choice for sampling airborne loads $[13,16,17,18]$. However, impactor air samplers are the most widely used for the quantification of air contamination $[19,20]$. Their advantage lies in the fact that agar plates can be incubated without further treatment, which means that colonies grow directly from collected viable airborne particles [20,21,22].

It is necessary to investigate hospital aerosols regularly, this may be done based on several purpose e.g. epidemiologic, surveillance, research, safety or quality control purposes[23]. Other studies have reported that occupant density is a key factor affecting concentrations of airborne bacteria, and humidity is also important depending on the particular location within the hospital [3]. However the significant particle concentration fluctuations in operating rooms may be related to variations in operating personnel numbers and activities [14].

A reported showed that Aspergillus infections, are primarily invasive pulmonary aspergillosis [24]. Building works carried out in the vicinity of ward areas can generate large aerosols of infective particles. Nevertheless there was no evidence of gross seasonal variation and it would appear that climatic conditions did not influence spore counts of A. fumigatus in the air [24]. Several authors have concluded that mould spores may enter the hospital through windows or inadequate air filtration systems $[25,26]$. This often occur in poor resource control setting especially in the third world countries. Surfaces, such as carpets, potted plants and multiple-hole false ceilings are potential sources of fungal contamination. Dust might accumulate in these areas and spores may enter the patient room as contaminants on personnel's clothing [26].

This study aimed at determining the variation in microbiota of five section in a tertiary healthcare facility in Okada. This study determine the most prevalent organisms from various section of the hospital and most affected section in the hospital.

\section{Materials and Methods}

\subsection{Study Area}

This work was done at Igbinedion University Teaching Hospital, Okada (IUTH) Edo, State, Nigeria. The hospital is situated in Okada, Ovia Northeast of Edo state. Igbinedion University Teaching Hospital is about $52 \mathrm{~km}$ from Benin City the state capital, it is a private institution that serve the okada community and its neighbourh community. As a teaching hoaspital all the variuos Unit in any standard teaching hospital are available, hence it serve as a referal hospital to the health center around. The hospital used for monitoring purposes is a modern hospital with a total bed capacity of 400 and a total staff of over 500 .

\subsection{Procedure}

Three agar based media plates viz. Nutrient agar, MacConkey agar and Sabouraud's dextrose agar were aseptically prepared and were exposed for $30 \mathrm{~min}$ at height of 6 feet above the ground in five units of the hospital. Exposure of another set of of plates were also done in afternoon and evening as well. The plates were then closed. Immediately after collection of samples, the agar plates were taken to the medical microbiology laboratory. These exposed agar plates were incubated in an inverted position at $28 \pm 12^{\circ} \mathrm{C}$ for $3-4$ days. Nutrient agar plates were incubated at $36^{\circ} \mathrm{C}$ for $24-48 \mathrm{hrs}$.

The total number of colony forming units (cfu) was enumerated and converted to organisms per cubic meter air. Bacterial colonies were initially characterized by morphology and microscopic examination and identified further by biochemical tests $[27,28]$. The fungal colonies were identified according to the manual of Barnett and Hunter [29], the tests were based mainly on gross colonial appearance, microscopic examination of the spore and hyphal characteristics of lactophenol cotton blue preparations.

\subsection{Microbial Estimation}

The number of colonies so appeared on exposed plates were counted. The number of microorganisms expressed as $\mathrm{CFU} / \mathrm{m} 3$ was estimated using Koch sedimentation method according to Polish Standard PN 89/Z-04008/08 [30], according to which,

$\mathrm{CFU} / \mathrm{m}^{3}=$ a. $10000 /$ p.t.0.2

a-the number of colonies on the Petri plate

p- the surface of the Petri plate

t- the time of Petri plate exposure

$$
\mathrm{cfu} / \mathrm{m}^{3}=\frac{\text { Colonies on agar stripes }}{\text { Sampling time in munites }} \times 25
$$

\section{Result}

The total heterotrophic microbial population of the five different wards of Igbinedion University Teaching Hospital were (Table 1 and Table 2).

The highest bacterial population recorded in the evening between time $5 \mathrm{pm}$ and $6 \mathrm{pm}$ compared to the morning and afternoon, ranging from $15 \mathrm{cfu} / \mathrm{m}^{3}$ to $47 \mathrm{cfu} /$ $\mathrm{m}^{3}$ so also fungi growth too. High bacterial population counts were observed in the children, female wards and the bacteriological laboratory in the three different times of studies (morning, afternoon and evening) which was shown in Table 1.

The concentration of fungal population in air of the five different wards in this hospital under study was recorded high in the evening, with values ranging from $10 \mathrm{cfu} / \mathrm{m} 3$ to $53 \mathrm{cfu} / \mathrm{m}^{3}$ (Table 2). At the three different times of 
study, the male, female, children wards and bacteriological laboratory were observed to record.

Table 3 shows the frequency distribution of the hospital air microorganisms isolated from five different wards of the Hospital. Seven bacterial isolates and four fungal isolates were isolated. Among the bacterial isolates Escherichia coli, Staphylococcu aureus, Staphylococcus epidermidis and Proteus mirabilis were observed to be the most prevailing isolates in all the units investigated, while Aspergillus sp. and Fusarium sp. were the fungal isolates most commonly frequent in all the units studied. The degree of frequency of microbial distribution was high in the bacteriological laboratory and female ward and lowest in the operating room (Theater).

Table 1. Concentration of bacterial population in air of five wards (cfu/m $\left.\mathbf{m}^{3}\right)$

\begin{tabular}{|c|c|c|c|}
\hline \multicolumn{2}{|c|}{ Sampling time } & 12:00noon-2:00pm \\
\hline Study area & $08: 00 \mathrm{am}-10: 00 \mathrm{am}$ & 5 & $1: 00 \mathrm{pm}-6: 00 \mathrm{pm}$ \\
\hline Male ward & 7 & 15 & 13 \\
\hline Female ward & 12 & 13 & 11 \\
\hline Children ward & 10 & 14 & 17 \\
\hline Theatre & 6 & 17 \\
\hline
\end{tabular}

Table 2. Concentration of fungal population in air of five different wards of Igbinedion University Teaching Hospital (cfu/m3)

\begin{tabular}{|c|c|c|c|}
\hline \multicolumn{4}{|c|}{ Sampling time } \\
\hline Study area & 08:00 am-10:00 am & $12: 00$ noon- $2: 00 \mathrm{pm}$ & 4:00 pm-6:00 pm \\
\hline Male ward & 8 & 9 & 6 \\
\hline Female ward & 7 & 10 & 5 \\
\hline Children ward & 8 & 9 & 7 \\
\hline Theatre & 3 & 5 & 2 \\
\hline Accident \& Emergency unit & 10 & 16 & 14 \\
\hline
\end{tabular}

Table 3. Frequency of occurrence of hospital air microorganisms isolated from the five wards

\begin{tabular}{|c|c|c|c|c|c|}
\hline Microbial isolates & Male ward & Female ward & Children ward & Theatre & Laboratory \\
\hline Pseudomonas aeuroginosa & - & + & - & - & ++ \\
\hline Escherichia coli & ++ & ++ & ++ & + & ++ \\
\hline Staphylococcus aureus & ++ & ++ & ++ & + & ++ \\
\hline Staphylococcus epidermidis & + & + & + & - & ++ \\
\hline Proteus mirabilis & + & + & + & + & + \\
\hline Klebsiella aerogenes & + & + & - & - & + \\
\hline Aspergillus sp & - & + & + & + & + \\
\hline Penicillium sp & - & ++ & ++ & - & ++ \\
\hline Mucor sp & + & - & + & - & + \\
\hline
\end{tabular}

\section{Discussion}

This study was conducted in a tertiary institution located in a rural where there is reduced industrial activities. It serve as indices to check the human activities as regard to hospital in rural area. In this country limited documentation had been seen on this study especially hospital in rural area where there is reduced human activities [31,32].

This research showed various effects of human activities on the microbiological quality of hospital air. In the study, five species of bacterial isolate, Staphylococcus aureus, Escherichia coli, Pseudomonas aeruginosa, Proteus mirabilis and Klebsiella aerogenes and three species of fungal isolates, which include Aspergillus sp, Penicillum sp, Mucor sp, were consistently isolated from the five different hospital units investigated. These genera of bacteria and fungi have been shown to be amongst the most common organisms often isolated from the air [33,34]. In a similar study following organisms were isolated Staphylococcus aureus, non-coagulase Staphylococci, Micrococcus spp, alpha hemolytic Streptococci, Diphtheroid bacilli, Gram negative bacilli, Bacillus spp, Streptomyces spp, unidentified bacteria and fungi from male, female, pediatric, female surgical and male surgical wards respectively, intensive care unit and operating theatre [35]. The fungal genera were Alternaria, Aspergillus, Chaetomium, Penicillum and Verticullum. Pseudomonas aeuroginosa an agent that had been highly associated with NI was the least organism isolated in this study, this agent had been found to be associated with open wound in hospital enviroment[36]. Quantitative study of different hospital units showed that the children ward and female ward had the highest total bacterial count followed by the bacteriology laboratory. The high microbial counts recorded for might be due to the fact that the hospital is location is a rural setting, the poor hygiene of the rural populace pose as sources of microorganism to the hospital. These findings could be explained by many factors including the number of visitors visiting the Accident and emergency wards, which exceeded visitors in other hospital units. It was also noted that the amount of materials brought from outside such as personal belongings, food and fruits were more common in this ward since fifty percent of the pateints are usually attended to at the Accident and emergency ward before moving them to their various ward. Notably, most of the patients that comes to this ward are brought under emergency hence family do come with dirty clothing as most of them are farmer. Although there are no established standards for viable or non-viable particulate in theatre or in other hospital areas, the number of microorganisms in the theatre was extremely low in this study. Human activities such as talking, walking, laughing, sweeping and coughing, all contribute to the microbial load in the air of this hospital. This result also confirms with report of Okhuoya and Okaraedje that human population and activities affects population of bacteria, which are released through human activities such as brisk movement, talking, coughing and sneezing [37].

Studies on microbial contaminants in indoor air have been recorded [33,38,39,40]. Earlier work in Benin city, 
Nigeria had shown contamination of hospital indoor both in private and goverment owned hospitals [31]. The concentration of potentially pathogenic organisms in the hospital air was low compared to the concentration of pathogenic bacteria carried out in an European study using an Anderson air sampler, pathogenic bacteria accounted for $30 \%$ of all isolates [41], but it included Streptomyces spp as human pathogens but in the study reported by Jaffal et al. [40], Streptomyces spp was considered an environmental microorganism. The low concentration of pathogenic organisms in the air could possibly be due to the fact that there was no strong air current to distribute the bacteria from the reservoirs (patients). Pathogenic organisms associated with wound infections would be expected in high concentration in certain hospital areas. They do not seem to be airborne and therefore their mode of transmission is most likely via direct physical contact of staff and patients.

The fungi isolates in this study were few compared to previous study [39], however it is closely related with observation of study done in Benin City Nigeria a less than two hundred kilometres $(20 \mathrm{Km})$ from this study area [31]. From this study, Staphylococcus aureus, Escherichia coli, Proteus mirabilis appeared to be the most prevalent bacteria species. Staphylococcus is known to be easily carried in the nasopharynx, throat, skin, cuts, boils, nails and as such can easily contribute to the microflora in the hospital environment [31]. Escherichia coli a gram negative, make up approximately $10 \%$ of microorganism of the humans and are used as the indicator organisms [42]. It is commonly associated with water and its presence in the environment reflects the degree of purity of the water used for various purposes e.g. floor cleaning and other activities in the hospital wards.

The most common fungi isolates frequently reported includes, Aspergillus spp Chaetomium and Alternaria and they are the most common genera frequently isolated from indoor environments and air conditioning systems [40]. The most common of them, Aspergillus, is occasionally involved in incidence of aspergillosis, ear and skin infections. It is therefore important to evaluate the quality of the air we breathe whether indoor or outdoor, especially in the hospital environments. The number and type of airborne microorganisms can be used to determine the degree of cleanliness as well as to determine the source of human discomfort.

Some of the organism isolated in this study had been listed in nosocomial infection [43]. In a recent investigation some of these organisms had been isolated from the fabric used in hospital especially the white coat $[43,44,45]$.

The limitations on of the time of visits in the hospitals leads to increase the number of people in hospital building in short period of time and consequently raise the airborne microbial rates at this period of time. Well-constructed ventilation systems and air-conditioning systems are needed to decrease the concentrations of microorganisms that may be introduced into the indoor air of hospitals. The kind of hospital, the type of room and the time of sampling are three factors that affect the indoor airborne microbial rates. More studies need to be done to establish a surveillance base on healthcare facilities in rural area in Nigeria. Further studies are needed to investigate the antibiotic-resistance patterns of isolated airborne microorganisms. Implementation of more stringent, frequent and comprehensive disinfection procedures should be applied in all healthcare facilities in rural health facilities. The continuous education of hospital authorities and health workers on principles of infection control through training and re-training is necessary.

\section{Reference}

[1] Chuaybamroong P, Choomseer P, Sribenjalux P (2008). Comparison between hospital single air unit and central air unit for ventilation performances and airborne microbes. Aerosol and Air Qual. Res, 8 (1): 28-36.

[2] McCarthy J, Luscuere P, Streifel A, Kalliokoski P (2000). Indoor air quality in hospitals and other health care facilities. In Proceeding of Healthy Buildings 2000, Espoo, Finland.

[3] Obbard J P, Fang L S (2003). Airborne concentrations of bacteria in a hospital environment in Singapore. Water, Air, and Soil Pollution 144: 333-341.

[4] Atlas RM (1995). Microorganisms and Human Diseases. In Microorganisms in Our World. Mosby-Year Book, Inc. P19-22

[5] Hambraeus A (1988). Aerobiology in the operating room- a review. J. Hosp.Infect. 11 (supp. A): 68-76.

[6] Emmerson AM (1995). The impact of surveys on hospital infection. J. Hosp. Infect. 30: 421-440.

[7] Gillette B (2000). Indoor air quality important. Mississippi Bus. J. 22 (47): 14-16.

[8] Nevalainen AK, Willeke F, Liebhaber J, Pastuszka A, Burge H, Henningson E (1993). Bioaerosol sampling. In K. Willeke and P. Baron (ed.), Aerosol measurement: principles, techniques and applications. Van Nostrand Reinhold, New York. p 321-324.

[9] Augustowska M, Dutkiewicz J (2006). Variability of airborne microflora in a hospital ward within a period of one year. Ann. Agric. Environ. Med. 13: 99-1 06.

[10] Matar GM, Chaar MH, Araj GF, Srour Z, Jamaleddine G, Hadi U (2005). Detection of a highly prevalent and potentially virulent strain of Pseudomonas aeruginosa from nosocomial infections in a medical center. BMC Microbiol. 5: 29-36.

[11] Montz JR, Edward W (2000). Contamination control in hospitals. Engineered Systems, 17 (6): 68-71.

[12] Abussaud MJ (1991). Prevalence of nosocomial infections in Saudi Arabian teaching hospital. J. Hosp. Infect. 17: 235-238.

[13] Shintani H, Taniai E, Miki A, Kurosu S, Hayashi F (2004). Comparison of the collecting efficiency of microbiological air samplers. J. Hosp. Infect. 56: 42-48.

[14] Li CS, Hou PA (2003). Bioaerosol characteristics in hospital clean rooms. Sci. Total Environ. 305: 169-176.

[15] Pasquarella C, Pitzurra O, Savino A (2000). The index of microbial air contamination. J. Hosp. Infect. 46: 241-256.

[16] Dharan S, Pittet D (2002). Review: Environmental controls in operating theatres. J. Hosp. Infect. 51: 79-84.

[17] Qudiesat, K, Abu-Elteen, K, Elkarmi A, Hamad, M, Abussaud, M.(2009) Assessment of airborne pathogens in healthcare settings African Journal of Microbiology Research, 3 (2): 066-076.

[18] Wu PC, Su HJ, and Ho HM (2000). A Comparison of sampling media for environmental viable fungi collected in a hospital environment. Environ. Res. Section A 82: 253-2.

[19] Nesa D, Lortholary J, Bouakline A, Bordes M, Chandenier J, Derouin F and Gangneux JP (2001). Comparative performance of impactor air samplers for quantification of fungal contamination. $J$. Hosp. Infect. 47: 149-155.

[20] Morris G, Kokki MH, Richardson MD (2000). Sampling of Aspergillus spores in air. J. Hosp. Infect. 44: 81-92.

[21] Gangneux JP, Gangneux FR, Gicquel G, Tanquerel JJ, Chevrier S, Poisson M, Aupee M, Guiguen C (2006). Bacterial and fungal counts in hospital air: comparative yields for 4 sieve impactor air samplers with 2 culture media. Infect Control Hosp Epidemiol. 27: 1405-1 408.

[22] Prigione V, Lingua G, Marchiosio VF (2004). Development and use of flow cytometry for detection of airborne fungi. Appl. Environ. Microbiol. 70: 1360-1365.

[23] Gröschel DHM (1980). Air sampling in hospitals. Ann. N. Y. Acad. Sci. 353: 230-240. 
[24] Goodley JM, Clayton YM, Hay RJ (1994). Environmental sampling for aspergilli during building construction on a hospital site. J. Hosp. Infect. 26: 27-35.

[25] Gerson SL, Parker P, Jacobs MR et al. (et al is not allowed please include all authors name) (1994). Aspergillosis due to carpet contamination. Infect. Control Hosp. Epidemiol. 15: 221-223.

[26] Pastuszka JS, Marchwinska-Wyrwal E, Wlazlo A (2005). Bacterial aerosol in Silesian hospital: preliminary results. Polish J. Environ. Studies 14 (6): 883-890.

[27] Tilak, S.T., (1982). Biology of airborne organism: Aerobiology, 1" edn. M.J. Vaidya publishers, pp: 148-258.

[28] Aneja, K.R., (2007). Experiments in Microbiology, Plant Pathology and Biotechnology. (IV Ed.) New Age International (P) Limited, Publishers. New Delhi. p145-156

[29] Cuppuccino, J.G. and N. Sherman, (2002). Techniques for isolation of pure culture In. Microbiology: a laboratory manual (VI Ed.) Person Education, Inc. Singapore. p132-133.

[30] Bhatica L and Vishwakarma R (2010). Hospital Indoor Airborne Microflora in private and Government owned Hospitals in Sagar City, India. World J. Med. Sci. 5 (3): 65-70

[31] Ekhaise, F.O., Ighosewe O.U. and Ajakpovi O.D. (2008). Hospital Indoor, Airborne Microflora in private and Government Owned Hospital in Benin City, Nigeria. World J. Medical Sci., 3(1): 19-23.

[32] Kesah, CN, Egri-Okwaji, M.T.C., Odugbemi, T O. and Iroha, EO. (1998). Resistance of Nosocomial Bacterial Pathogens to commonly used Antimicrobial Agents. The Nigerian Postgraduate Medical Journal 6 (2): 60.64

[33] Ekhaise F O and Ogboghodo B I (2011) Microbiological Indoor and Outdoor Air Quality of Two Major Hospitals in Benin City, Nigeria. Sierra Leone J Biomed Res 3 (3): 169-174

[34] Burge, H.A. and M.E. Hoyer, (1990). Indoor air quality. Applied Occupational Environment Hygiene. 5: 84-93.

[35] Jaffal AA, Nsanze H, Bener A, Ameen AS, Banat IM, El Mogheth AA (1997). Hospital airborne microbial pollution in a desert country. Environ. Internat. 23: 167-172.

[36] Ehiaghe, F. A., Ehiaghe, I. J., Agbonlahor, D. E., Oviasogie, F. E., Etikerentse, S. M. O., Nwobu, R. A. U., Akinshipe, B. O.,
Ikusemore, A. I., Aladenika, S. T. and Enwa, F. O. (2013) Plasmid Profiling and Curing Analysis of Fluoroquinolone Multidrug Resistant Pseudomonas aeruginosa in Benin City, Nigeria OJMM, 3: 201-205

[37] Okhuoya, J.A. and S.O. Okaraedge, 1992. Microflora of road side air and leaf surfaces of selected vegetables. Nigerian Journal of Pure and Applied Science, 12: 42-48.

[38] Samuel,S. O, Kayode,O. O, Musa,O. I, Nwigwe,G.C, Aboderin A.O, Salami T.A.T and Taiwo S.S (2010). Nosocomial infections and the challenges of control in developing countries. Afr. J. Cln. Exper. Microbiol 11 (2): 102-110

[39] Ayanru, D.K.G., (1981). Agricultural and clinical significance of some microbial components of the air spores in the Benin-city area. In: Global impact of Applied Microbiology. 6th International Conference. Emejuae, Oguhbi and Sanni (Eds.). Academic Press London, pp: 107-117.

[40] Jaffal, A.A., I.M. Banat, A.A. El Mogheth, H. Nsanze, A. Benar and A.S. Ameen, 1997. Residential indoor airborne microbial populations in the United Arab Emirates. Environ Internat. 23 (4): 529-533.

[41] Williams, R.E., O.M. Lldwell and A. Hirch, (1965). The bacterial flora of the air of occupied rooms. Journal of Hygiene, 54: 512523.

[42] Prescott, L.M., J.P. Harley and D.A. Klein, 2005. Microbiology. 6th edn. McGraw Hill Co., New York, pp: 92.

[43] Uneke C. J. and P. A. Ijeoma (2010) The Potential for Nosocomial Infection Transmission by White Coats Used by Physicians in Nigeria: Implications for Improved Patient-Safety Initiatives. World Health Popul. 11 (3): 44-54.

[44] Kotsans, D., C. Scott, E.E. Gillespie and T.M. Korman. 2008. "What's Hanging around Your Neck? Pathogenic Bacteria on Identity Badges and Lanyards." Medical Journal of Australia 188 (1): 5-8.

[45] Loh, W., V.V. Ng and J. Holton. 2000. "Bacterial Flora on the White Coats of Medical Students." Journal of Hospital Infection 45 (1): 65-8. 